\title{
Undergraduate students: interactive, online experiences and ePortfolio development
}

\author{
Wendy Beresford, David Cobham \\ Lincoln School of Computer Science \\ University of Lincoln \\ Lincoln, UK. \\ wberesford@lincoln.ac.uk,dcobham@lincoln.ac.uk
}

\begin{abstract}
Results of a previous study by the authors into the perceived value and potential of ePortfolios to assist undergraduate students indicated that technology was an important aspect of their everyday lives. It was also felt it to be beneficial to their learning. A large percentage of students were found to be using digital techniques to store evidence of their learning, and were also using interactive, online tools in their learning activities. There was, however, little reported structured use of ePortfolio development in their learning. Students acknowledged they were discovering for themselves the value of online technologies in learning.
\end{abstract}

This paper focuses on student skills and experiences of online tools on entry to university, and considers their experience of ePortfolio development using the Wordpress personal publishing platform.

Results indicate that students' skill level of online, interactive tools was high and wide-ranging. Although previous experience of using these tools was unstructured and informal, ePortfolio creation was found to be an engaging, relevant and worthwhile activity.

The ePortfolio development exercise also provided an experiential learning experience, and had a positive effect on students' attitudes to learning.

Keywords-ePortfolios; higher education; learning; Web 2.0.

\section{INTRODUCTION}

The emergence of interactive, web-based software tools has led to a generation of people who are occupied, even pre-occupied, with creating a digital archive of their lives. Whether by recording and sharing daily events or storing multimedia artifacts, today's digital natives are becoming digital curators of their own life experiences.

The digital divide remains evident in the UK due to socio-economic and geographical barriers [1]. Therefore, it should not be taken for granted that all students entering higher education are digital natives, having an "always on" connection to the Internet and virtual personas.

However, many young adults do have varying levels of ICT and online skills, knowledge and experience. These are gained in a variety of settings including the home, school and work.
Seventy-three percent of UK households now have Internet access, and an increasing-range of online activities are changing everyday living, communication, and driving social change. Social networking, shopping and watching television on the Internet are all popular online activities [2].

Education is also being affected by the connected, online developments reported above. Some would say learning is becoming a more social experience and is concerned with learners forming networks with each other [3]. This view is supported by Futurelab, who report that through the use of interactive technologies known as social software, learners can come together, build communities and share information [4]. In defining the term social software Shirky states that "we are still learning how to build and use the software-defined conference tables and campfires we're gathering around" [5]. Indeed, the effective use of this technology in teaching and learning requires that institutions adopt a student-centred approach to pedagogy.

As well as supporting individual activity, technology can be used to facilitate collaborative learning and to monitor student progress in collaborative environments. Jermann et al reported on student use of on-line technologies in providing repository and documentation facilities [6]. Wang reports on the use of several tools (Drop.io, Google Groups, PBworks, and Facebook Group) to encourage and support collaborative working. He found that these tools added potential for monitoring the collaborative learning process but concluded that this was most effectively done alongside traditional face-to-face approaches [7].

Authors have identified learner preference in the use of web-hosted material [8] [9]. Research has shown that learner preference for a particular on-line resource is essential if the learner is to benefit from its use [10]. A survey of students of the Spanish language found that they were guided by their learning preferences in their use of online content [11].

Policy initiatives around employability, achievement, personalisation and the skills agenda, coupled with institutional drivers including personal development planning (PDP), mean this new approach is being made 
possible. Gray and Joyes also explain that the emergence of personal development planning in higher education has led to the implementation of ePortfolios [12].

Chang et al reflect on the effect that previous experience of portfolio usage might have when ePortfolios are introduced. In a study that considers various models of technology acceptance Chang et al identify that traditional paper-based portfolios are prevalent in subjects such as art, architecture and teacher training. They recommend bringing acceptance testing to the earliest possible phase in the development cycle in order to establish perceived values and thereby predict the users' attitudes regarding acceptance of ePortfolios [13].

Rebbeck suggests, "the ePortfolio is the central and common point for the student learning experience... It is a reflection of the student as a person undergoing continuous personal development, not just a store of evidence" [14].

ePortfolios can facilitate a student-centred and personalised approach to learning in a connected world. However this raises the question of the extent to which traditional learning theories still valid in technologyenhanced models of learning. A report by the Joint Information Systems Committee, suggests that David Kolb's experiential learning cycle can be adapted to provide "continuous learning based around dialogue and collaborative activity with others" [15][16].

Electronic portfolios can serve many purposes and audiences. Indeed, they have been defined as both 'process' and 'product'. For example, in the case of a presentation, or showcase portfolio - the product is the portfolio, but for a working portfolio - the process is the portfolio [17].

Studies [18] [19] [20] have shown that positive benefits can be derived from the use of ePortfolios in education both as multimedia repositories and as tools to assist learning.

\section{AIMS AND OBJECTIVES}

This paper forms part of a wider, ongoing project by the authors looking at the effective use of ePortfolios in Higher Education [21]. The aim of this stage of the research was to focus on the skills and experiences of a group of students at entry to their programme and the effect on that group of introducing the structured and formal use of ePortfolios.

The objectives were:

- to establish the skills and experience of the cohort on entry to university;

- $\quad$ to establish the current student perception of ePortfolio development in helping to manage their learning

- $\quad$ to create an intervention whereby student experienced initial workspace ePortfolio development;
- to evaluate the practical ePortfolio creation sessions through the use of an online quantitative survey and practical ePortfolio creation sessions;

- to seek relationships between skills on entry and the overall success of the ePortfolio development exercise.

\section{METHODOLOGY}

A pragmatic, mixed-method approach was taken to gain an understanding of student experiences of using interactive Web 2.0 tools, their perception of ePortfolios in learning, and initial experience of ePortfolio creation. Investigations conducted were practical in nature, but differed in design and approach.

\section{Research methods}

The following methods were utilised:

- an online, quantitative survey investigating prior knowledge and experience of online, interactive, Web 2.0 tools, electronic storage of work, experience and perception of ePortfolio creation;

- analysis and interpretation of survey data;

- observation to monitor levels of student engagement during ePortfolio workshops;

- individual written responses to open-ended questions from a smaller focus group of students, detailing their individual experiences of ePortfolio creation to provide additional, qualitative data.

\section{Implementation}

A new level one cohort of students following an undergraduate, technology-based programme was selected and asked to complete the online survey.

Students were then introduced to the concept of ePortfolios and how they could be used as a tool to manage their learning, before development began. The ePortfolios were developed using Wordpress, a Web 2.0 personal publishing tool, during supervised workshop sessions. They were tasked to create an ePortfolio, suitable for use as an online repository for digital artefacts including text, images, audio and video. The intention was that the ePortfolio should be developed for use across the various modules being studied and over time thereby building a story of their learning experiences, achievements, and eventually becoming a reflective learning tool. 


\section{FINDINGS}

A. Student survey investigating prior knowledge and experience of online, interactive, Web 2.0 tools, electronic storage of work, experience and perception of ePortfolio creation.

A total of 51 students responded to the survey. Findings were as follows:

- Gender: $88 \%$ male, $12 \%$ female.

- Age: The majority of respondents belonged to the 18-23 years age range.

- Social networking: The majority of students reported having 'very good' knowledge and experience of social networking tools such as Facebook.

- Online tools used in learning: YouTube, Flickr and blogs were popular with the majority of students.

- Wikis: The majority of students reported having 'some' knowledge and experience.

- Web services: The majority of students reported having 'good' knowledge and experience.

- Tagging: The majority of students reported having 'good' knowledge and experience.

- eLearning: The majority of students reported having higher levels of 'some knowledge and experience.

- eGovernment: The majority of students reported having 'no' knowledge and experience.

- Electronic storage of work: The majority of students reported keeping copies of their work and CV's digitally.

- Storage medium: The majority of students indicated they were storing work on a PC. Mobile devices were also a popular choice.

- ePortfolio creation: The majority of students reported having no prior experience of ePortfolio development.

- Perceived uses of an ePortfolio: Students indicated using an ePortfolio as an everyday repository to access and store digital content would be of benefit to them they also felt using an ePortfolio to showcase learning and achievement would also be a major benefit. The majority felt they would continue to develop their portfolios after graduation.

\section{B. ePortfolio workshop sessions}

The student cohort participated in two supervised ePortfolio development workshop sessions. Students were provided with supporting, introductory notes and documentation on ePortfolio development. Findings and observations were as follows:
- Students were observed as being motivated, engaged and on task.

- In their own time between sessions many students had accessed and further developed their portfolio.

- Personalisation of ePortfolios was found to be very important to students. Changes to page layout/colours/fonts, theme changes, creation of additional pages, menu structure to reflect content and page content were some of the ways in which personalisation was achieved.

- When asked what aspect they enjoyed the most about creating their portfolios, students indicated personalisation, timely expression of thoughts, seeing how their work has progressed and how much they've learned, and being able to create an online presence people would be interested in viewing.

- All students successfully created an ePortfolio. Whilst some students felt Wordpress was intuitive and straightforward to use, some felt the technology was driving them - at least until they had gained a better understanding of Wordpress.

- Students indicated they would be accessing their portfolios regularly (some daily) for different purposes including the management of university work, to showcase achievements, and to communicate their thoughts.

- When asked if creating an ePortfolio had made them feel different about their learning, students indicated that it had helped them to focus on themselves and their work. Other comments included their ePortfolio was helping them to learn by "doing".

\section{CONCLUSIONS}

The purpose of this research was to establish the skills and experience of the student cohort on entry, and seek relationships between those skills and the overall success of the ePortfolio development exercise.

All students successfully developed an ePortfolio. They were engaged in the exercise from the outset and required little guidance and assistance. Through observation and individual comments the majority of students found the platform intuitive and the personalisation element was considered to be an important aspect of the development process for most students. Engagement levels in the workshop sessions were high and within a short space of time many students created a significant amount of textual and multimedia content relating to their study modules.

Following the development of their ePortfolios, initial views expressed by students remained unchanged. They would continue to use them for two main purposes: as an 
everyday learning tool, and to show case to demonstrate work.

Possibly the two most important comments from students in terms of ePortfolio development benefitting the learning process, were: "learning by doing", echoing the sentiments of Kolb's experiential cycle learning theory [21] and "I think it [the portfolio] has focused me and is aiding me in focusing my work", which indicates students being better placed to take ownership of their learning and confirms Rebbeck's findings of the centrality of ePorfolios in the learning experience [12].

The success of the ePortfolio creation exercise would suggest that students are enthusiastic and willing to use these tools in learning. The level and the extent of success in their usage did not appear to be directly linked to prior knowledge of the Web 2.0 technologies employed although such knowledge did allow a more rapid implementation to be developed.

This research was carried out with a relatively small and prescribed cohort of students. The next stage of the research will go on to track and evaluate ePortfolio usage over time and introduce the trialling of new aspects of ePortfolio interaction, including that of mobile devices. It will also broaden the base away from technology students whose prior knowledge may mean they are predisposed to adopting these tools.

\section{REFERENCES}

[1] M.L. Fox, 2009. Digital divide in the UK? [Online]. Available from: http://www.21stcenturychallenges.org/focus/digital-divide-in-britain/

[2] Office for national Statistics, 2010. Internet Access [Online]. Available from: http://www.statistics.gov.uk/cci/nugget.asp?id=8.

[3] G. Siemens, 2010. The impact of social software on learning [Online]. Available from: http://www.youtube.com/watch?v=grI_h88vs3g.

[4] Futurelab, 2006. Social software and learning [Online]. Available from: http://www.futurelab.org.uk/resources/publications-reportsarticles/opening-education-reports/Opening-Education-Report199/.

[5] C. Shirky, 2003. Social software and the politics of groups [Online]. Available from: http://www.shirky.com/writings/group politics.html M. Young, The Technical Writer's Handbook. Mill Valley, CA: University Science, 1989.
[6] Jermann, P., Soller, A., \& Lesgold, A. (2004). Computer software support for CSCL. In J. W. Strijbos, P. A. Kirschner, \& R. L. Martens (Eds.), What we know about CSCL (pp. 141-166). Norwell, MA: Kluwer Academic Publishers

[7] Q. Wang, 2010. Using online shared workspaces to support group collaborative learning. Computers \& Education 55 (2010) 12701276.

[8] Y.T. Yang and C.Y. Chan, 2008. Comprehensive evaluation criteria for English learning websites using expert validity surveys. Computers \& Education, 51(1), 403-422.

[9] S. Ozkan and R. Koseler, 2009. Multi-dimensional students' evaluation of e-learning systems in the higher education context: an empirical investigation. Computers \& Education, 53(4), 1285-1296.

[10] K.A. Pituch and Y.K. Lee, 2006. The influence of system characteristics on e-learning use. Computers \& Education, 47(2), 222-244.

[11] 11 J.M. Sykes and A.D. Cohen, 2008. Observed learner behavior, reported use, and evaluation of a website for learning Spanish pragmatics. In M. Bowles, R. Foote, \& S. Perpiñán (Eds.), Second language acquisition and research: Focus on form and function. Selected proceedings of the 2007 second language research forum (pp. 144-157). Somerville, MA:Cascadilla Press.

[12] L. Gray and G. Joyes, 2010. Mahara UK 2010 keynote [Online]. Available from: http://www.maharauk.org/view/view.php?id=133

[13] C.C. Chang, K.H. Tseng, H.P. Yueh and W.C. Lin, 2010. Consideration factors and adoption of type, tabulation and framework for creating e-portfolios, Computers \& Education $<$ Accepted 8 Sept 2010> (2010) 1-14.

[14] G. Rebbeck, 2008. Effective Practice with e-Portfolios. Bristol, JISC.

[15] Joint Information Systems Committee, 2008. Effective Practice with e-Portfolios. Bristol, JISC.

[16] D.A. Kolb, 1984. Experiential learning: experience as the source of learning and development. London, Prentice-Hall.

[17] Barrett, 2010. ePortfolio California Summit. What is an ePortfolio? [Online]. Available from: http://blog.helenbarrett.org/

[18] G. Attwell, 2007. The personal learning environments - The future of eLearning? eLearning Papers, 2(1). Available from: http://www.elearningeuropa.info/files/media/media11561.pdf

[19] E. Meyer, P. Abrami, A. Wadea, O. Aslan and L. Deault, 2009 Improving literacy and metacognition with electronic portfolios: Teaching and learning with ePEARL, Computers \& Education 55 (2010) 84-91.

[20] H.C. Barrett, 2009. Online personal learning environments: Structuring electronic portfolios for lifelong and life wide learning. On the Horizon, 17(2), 142-152. Available from: http://docs.google.com/Doc?id=dd76m5s2_39fsmjdk

[21] W. Beresford and D. Cobham, 2010. The role of ePortfolios in higher education: their perceived value and potential to assist undergraduate computing students. EDULEARN10 International Conference on Education and New Learning Technologies (EDULEARN10). Barcelona, Spain 2010. 